\title{
Study of Genetic Variability for Cane Yield and its Component Traits in Early Maturing Sugarcane
}

\author{
Relisha Ranjan* and Balwant Kumar
}

Department of Plant Breeding and Genetics, SRI, Dr. Rajendra Prasad Central Agricultural

University, Pusa, Samastipur (Bihar), India

*Corresponding author

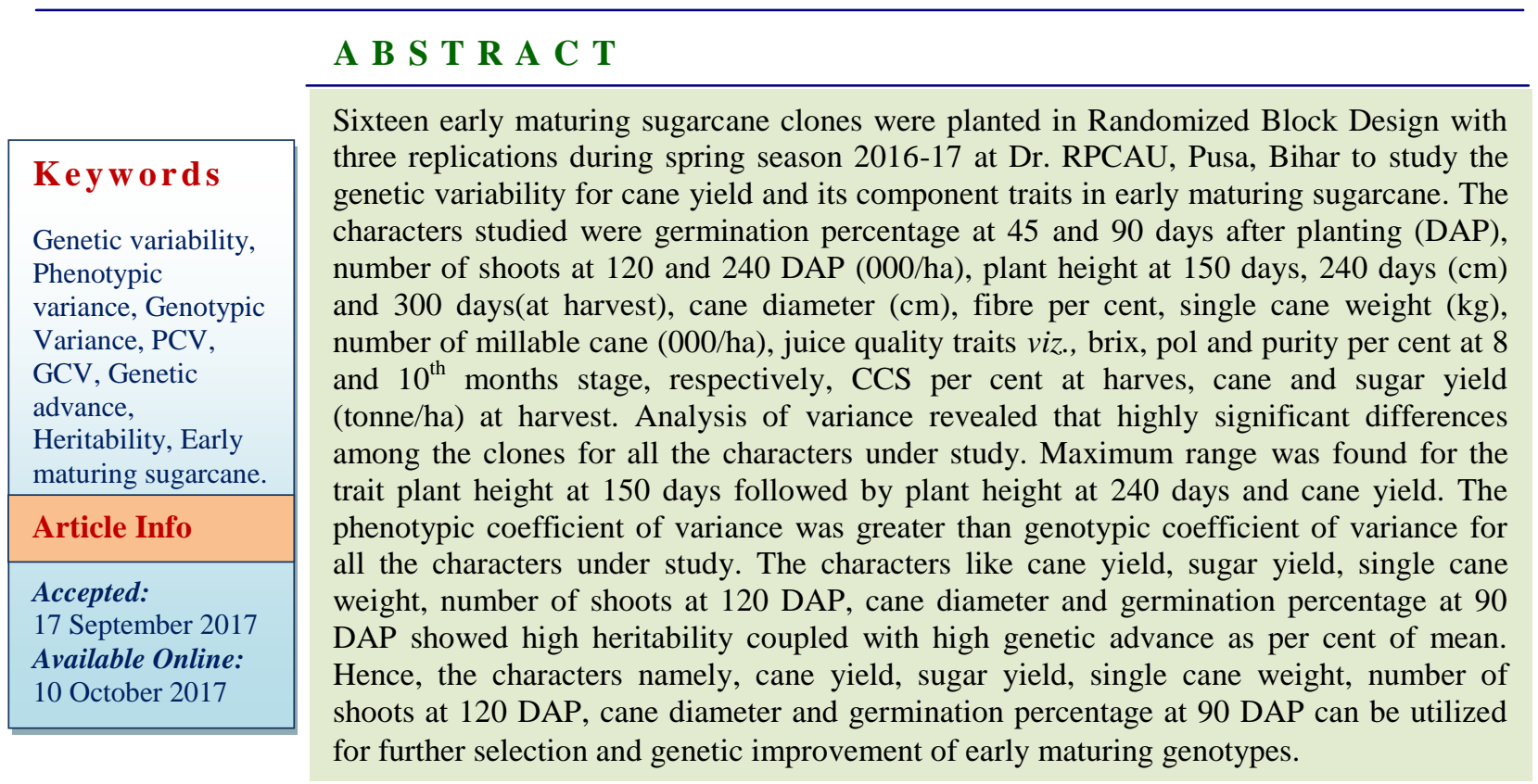

\section{Introduction}

Sugarcane is a highly heterozygous and complex polyploidy in nature and this crop has resulted in generation of genetic variability. Sugarcane improvement involves hybridization followed by clonal propagation. After hybridization large number of seedlings generated every year in which wide range of variability existed among the seedlings for cane and sugar yield and its component traits, therefore genetic variability is one of the important considerations in sugarcane crop improvement. Variability is measure by estimation of genotypic and phenotypic variance $\left(\sigma^{2} \mathrm{~g}\right.$ and $\left.\sigma^{2} \mathrm{p}\right)$, genotypic and phenotypic coefficient of variation (GCV and PCV), heritability, genetic advance and genetic advance as per cent of mean. These parameters help in selection for improvement of desired characters. Environment plays an important role in the expression of phenotype. The phenotypic variability which is observable includes both genotypic (heritable) and environmental variation (non-heritable). Hence, variability can be observed through 
biometric parameters like GCV, heritability (broad sense) and genetic advance. Development of varieties for different maturity group is of paramount importance in sugarcane cultivation to realize higher recoveries in sugar mills. Crushing early varieties at the start of season would increase the sugar recovery. Genetic variability for cane in the sub-tropical sugarcane gene pool has been found high which can be utilized for developing commercial varieties with high yield and sugar recovery. A clear cut understanding of variability of qualitative and quantitative characters of the breeding material is essential for breeder. Since the breeder is concerned with selection of superior genotypes for which the most suitable individuals from their phenotypic expression. Estimates of genotypic and phenotypic variance for various quantitative characters and their heritability are necessary.

Estimates of heritability and genetic advance expected by selection for yield via its components are useful in designing an effective breeding programme. Selection for yield could be made more efficiently and effectively on the basis of components traits. The pivotal of any breeding programme is the variation present in a gene pool along with flow of heritability.

The variability can be statistically differentiated into heritable variation and nonheritable variation. It is the heritable variation which is selected for high productivity. Heritability provides the information regarding the proportion of total variation in a progeny which is transmissible from generation to generation. Genetic advance provides information on expected genetic gain resulting from selection of superior individuals and idea of the amount of reduction of environmental effects for comparing the range of variability present in a population with respect to yield.

\section{Materials and Methods}

The material of this investigation comprises of 16 promising early maturing sugarcane clones viz, CoP 11436, CoP 11437, CoP 11438, CoSe 11451,CoLk 12207, CoLk 12208, CoP 12436, CoP 12437, CoSe 12451, CoP 14436, CoP 14437, CoP 15436, CoP 15437, BO 130, BO 153 (C) and CoSe 95422 (C). All the 16 early maturing sugarcane clones including two checks viz., BO 153 and CoSe 95422 were planted in Randomized Block Design with three replications during spring season 2016-17 at Dr. RPCAU, Pusa, Bihar followed all the recommended package and practices for raising sugarcane good crop. Three buded setts of all the clones were planted under field condition along with checks and from each replication each variety was planted in a plot of 4 rows of 3 meters length each with a spacing of 0.75 meter between rows.

Follow Patel and Patel (2014) for sugarcane sett size, seed rate and sett treatment. Observation were recorded by selecting five random plants per genotype per replication for component traits of cane yield and juice quality characters viz., germination percentage at 45 and 90 days after planting (DAP), number of shoots at 120 and 240 DAP (000/ha), plant height at 150 days, at 240 days (cm) and at harvest, cane diameter at harvest (cm), fibre per cent at harvest, single cane weight $(\mathrm{kg})$, number of millable cane at harvest (000/ha), juice quality traits viz., brix, pol and purity per cent at 8 and $10^{\text {th }}$ months stage, respectively, CCS per cent at harves, cane and sugar yield (t/ha) at harvest.

\section{Statistical analysis}

In order to assess and quantify the genetic variability among the genotypes for the characters under study, Estimation of variance components viz., phenotypic variances $\left(\sigma^{2} \mathrm{p}\right)$ 
and genotypic variances $\left(\sigma^{2} g\right)$ were estimated using the following formula as suggested by Panse and Sukhatme (1967).

$\sigma^{2} \mathrm{~g}=\frac{M S S(\text { genotypes })-\sigma^{2} e}{r}$

$\sigma^{2} p=\sigma^{2} g+\sigma^{2}$ e [When Cov. G x E=0]

Where,

$\sigma^{2} \mathrm{e}=$ Environmental variance i.e. error variance $=$ MSS (error) and $r=$ Number of replication

Genotypic and phenotypic coefficient of variation present in the cane yield and yield contributing characters were computed as per the method suggested by Burton and Devane (1953).

Genotypic coefficient of variability (GCV)

$\mathrm{GCV}=\sqrt{\frac{\sigma^{2} \mathrm{~g}}{\overline{\mathrm{x}}}} \times 100$

Where,

$\sigma^{2} \mathrm{~g}=$ Genotypic variance and $\overline{\mathrm{X}}=$ Population mean

Phenotypic coefficient of variability (PCV)

$\mathrm{PCV}=\sqrt{\frac{\sigma^{2} \mathrm{p}}{\bar{x}}} \times 100$

Where, $\sigma^{2} \mathrm{p}=$ Phenotypic variance and $\overline{\mathrm{X}}=$ Population mean

GCV and PCV values were categorized as low $(0-10 \%)$, moderate $(10-20 \%)$ and $\operatorname{high}(20 \%$ and above)

Heritability (Broad sense) in broad sense was estimated as the ratio of genotypic to the phenotypic variance and was expressed in percentage. It was calculated by the formula given by Johanson et al., (1955a).

$h^{2}($ Broad sense heritability $)=\frac{\sigma^{2} g}{\sigma^{2} p} \times 100$

Where,

$\sigma^{2} g=$ Genotypic variance, $\sigma^{2} p=$ Phenotypic variance and $\mathrm{h}^{2}=$ Heritability (broad sense heritability)

The heritability was categorized as low, moderate and high as given by Robinson et al., (1949).0-30\%: Low, 30-60\%: Moderate and $60 \%$ and above: High.

Genetic advance was estimated by using the formula suggested by Lush (1949) and followed by Johnson et al., (1955a) and Allard (1960).

Genetic advance $($ G.A $)=$ K. $\sigma$ p. $\mathrm{h}^{2}$

Where, $\mathrm{K}=$ Selection differential which is 2.06 at $5 \%$ selection intensity in large sample from normally distributed population, Phenotypic standard deviation and $\mathrm{h}^{2}=$ Heritability in broad sense

Genetic advance as percentage of mean was calculated by following formula:

$\mathrm{GA}($ as per cent of mean $)=\frac{\mathrm{GA}}{\overline{\mathrm{x}}} \times 100$

Where,

GA $=$ Genetic advance and $\overline{\mathrm{X}}=$ Mean of the character

Genetic advance as per cent mean was categorized as low, moderate and high as given by Johnson et al., (1955a).It is as follows. 
0-10\%: Low

10-20\%: Moderate

$20 \%$ and above: High

All the statistical analyzed data are being presented in Tables 1, 2 and 3. Observed data are also presented in Graph 1, which showed Estimate of ECV, GCV, PCV, $\mathrm{h}^{2}$ and GAM of characters in early maturing Sugarcane clones.

\section{Results and Discussion}

Variability among the early maturing sugarcane clones is the present need of sugarcane improvement programme. The analysis of variance as per overview given in Table 1 clearly indicated that highly significant differences were found among the clones for all the characters under studied. Similar results were also reported by earlier workers Ebid, et al., (2015), Hiremath and Nagaraja (2016), Tena et al., (2016), Agrawal and Kumar (2017) and Kumar et al., (2017), it means there wwer sufficient variability existed in the early maturing sugarcane for cane and sugar yield. Therefore wide range for such traits viz., cane and sugar yield favor towards selection of high cane yield as well as high sugar containing clones. In present investigation it was found that phenotypic variation for all the characters under study were higher than the genotypic variances. This may be due to the non-genetic factor which played an importance role in the manifestation of these characters. This result was in accordance with the findings of Doule and Balasundaram (2002) for brix and sucrose juice percentage, purity coefficient, commercial cane sugar, pol per cent cane and CCS per plot. Wide range of phenotypic and genotypic variance were observed for cane height at harvest followed by plant height at 240 DAP and purity per cent during 10 month stage from the perusal of Table 2. The assessment of heritable and non-heritable component in the total variability observed is indispensable in adopting suitable breeding procedure. The heritable portion of the overall observed variation can be ascertained by studying the component of variation such as GCV, PCV, heritability and genetic advance as per cent of mean. The high phenotypic coefficient of variance was observed for sugar yield followed by germination per cent at 90 DAP, cane yield and single cane weight from the perusal of Table 3. However, high genotypic coefficient of variation was observed for germination per cent at 90 DAP followed by sugar yield, single cane weight, these results are in agreement with Dilnesaw et al., (2016), Swamy Gowda et al., (2016), Bairwa et al., (2017) and Mehareb and Abazid (2017). Study of per se performance of individual genotypic suggests the importance of the materials under study and it becomes first hand information for the breeders. The mean of different quantitative character including sugar yield and cane yield as performed by the available clones suggested that selection of desirable clone based on the characters from material evaluated, cane be effective. Heritability estimates are useful in deciding the character to be considered while making selection, but selection based on this factor alone may limit the progress, as it is prone for change with environment, material etc. (Johanson et al., 1955). In other words, estimate of heritability have a role to play in determining the effectiveness of selection for a character, provided they are considered in conjugation with the genetic advance as per cent of mean as suggested by Panse (1942) and Johanson et al., (1955). In this study, heritability for the characters namely germination percentage at 90 DAP, singe cane weight, number of shoots at 120 DAP, brix per cent during 8 month stage, pol per cent during 8 month stage, cane diameter, plant height at harvest, cane yield and plant height at 150 days found to be high in sugarcane from the perusal of Table 3. So, 
these characters may be used as selection criteria in sugarcane for further improvement of clones. These finding were in confirmation with the results of earlier workers namely Chaudhary (2001) for stalk diameter and single cane weight, Kumar et al., (2004) for single cane weight, stalk girth and stalk height, Thippeswamy et al., (2001) for germination percentage and cane yield, Jamoza et al., (2014) for stalk diameter and stalk weight and Dilnesaw et al., (2016) for cane yield. High genetic advance was observed for the characters viz., germination percentage at 90 DAP, number of shoots at 120 DAP, Cane diameter at harvest, single cane weight, cane yield and sugar yield. Similar results were also reported by earlier workers Mali et al., (2010) for number of tillers and single cane weight, Ebid et al., for stalk weight, Sanghera et al., (2015) for stalk length and number of shoots. The coefficient of variance indicated the extent of variability present in the character and does not indicate the heritable portion. This could be ascertained from the heritability estimates which in broad sense include both additive and non-additive gene effects and in narrow sense include the portion of heritable variation which is due to addititive component (Lush, 1949). Assessing merits and demerits of particular characters as it enables plant breeders to decide the course of selection procedures are followed under a given situation. Hence, direct selection can be done through these characters for future improvement of clones for higher cane and sugar yield in early maturing sugarcane clones.

Table.1 Analysis of variance for twenty characters in early maturing sugarcane clones

\begin{tabular}{|c|c|c|c|c|}
\hline \multirow[b]{2}{*}{ S. $\mathbf{N}$. } & \multirow[b]{2}{*}{ Characters } & \multicolumn{2}{|c|}{ Mean sum of Square } & \multirow[b]{2}{*}{ F-Value } \\
\hline & & $\begin{array}{c}\text { Treatment } \\
(\text { d.f }=15)\end{array}$ & $\begin{array}{c}\text { Error } \\
(\text { d.f }=\mathbf{3 0})\end{array}$ & \\
\hline 1. & Germination percentage at 45 DAP & $40.12^{* *}$ & 8.36 & 4.80 \\
\hline 2. & Germination percentage at 90 DAP & $220.75 * *$ & 16.72 & 13.19 \\
\hline 3. & Number of shoots at 120 DAP (000/ha) & $482.73 * *$ & 40.07 & 12.04 \\
\hline 4. & Number of shoots at 240 DAP (000/ha) & $313.91 * *$ & 68.70 & 5.56 \\
\hline 5. & Plant height at 150 days $(\mathrm{cm})$ & $321.22 * *$ & 53.76 & 5.97 \\
\hline 6. & Plant height at 240 days $(\mathrm{cm})$ & $951.58 * *$ & 194.23 & 4.89 \\
\hline 7. & Plant height at harvest $(\mathrm{cm})$ & $3007.51 * *$ & 344.63 & 8.72 \\
\hline 8. & Cane diameter at harvest $(\mathrm{cm})$ & $0.34 * *$ & 0.03 & 9.89 \\
\hline 9. & Fibre per cent at harvest & $0.76^{* *}$ & 0.27 & 2.78 \\
\hline 10. & Single cane weight $(\mathrm{kg})$ & $0.04 * *$ & 0.003 & 13.20 \\
\hline 11. & Number of millable cane at harvest $(000 / \mathrm{ha})$ & $206.63 * *$ & 61.94 & 3.33 \\
\hline 12. & Brix per cent during 8 month stage & $3.61 * *$ & 0.35 & 10.30 \\
\hline 13. & Pol per cent during 8 month stage & $2.84 * *$ & 0.28 & 10.16 \\
\hline 14. & Purity per cent during 8 month stage & $1.37 * *$ & 0.25 & 5.37 \\
\hline 15. & Brix per cent during 10 month stage & $1.05 * *$ & 0.21 & 4.95 \\
\hline 16. & Pol per cent during 10 month stage & $0.53 * *$ & 0.12 & 4.33 \\
\hline 17. & Purity per cent during 10 month stage & $2.05 * *$ & 0.57 & 3.60 \\
\hline 18. & Cane yield (tonne/ha) & $512.19 * *$ & 73.16 & 7.00 \\
\hline 19. & CCS per cent at harvest & $0.21 * *$ & 0.05 & 4.01 \\
\hline 20. & Sugar yield (tonne/ha) & $8.93 * *$ & 1.43 & 6.25 \\
\hline
\end{tabular}


Table.2 Range, mean, genotypic and phenotypic variance of the characters in early maturing sugarcane clones

\begin{tabular}{|c|c|c|c|c|c|}
\hline S. N. & Characters & Range & Mean & $\sigma_{\mathrm{g}}^{2}$ & $\sigma_{p}^{2}$ \\
\hline 1 & Germination percentage at $45 \mathrm{DAP}$ & $27.10-39.10$ & 32.12 & 10.58 & 18.94 \\
\hline 2 & Germination percentage at 90 DAP & $44.55-75.11$ & 56.80 & 68.01 & 84.73 \\
\hline 3 & Number of shoots at 120 DAP (000/ha) & $82.24-124.33$ & 104.96 & 147.55 & 187.62 \\
\hline 4 & Number of shoots at 240 DAP (000/ha) & $108.67-145.02$ & 130.56 & 81.15 & 150.44 \\
\hline 5 & Plant height at 150 days $(\mathrm{cm})$ & $80.12-121.21$ & 97.48 & 89.73 & 142.91 \\
\hline 6 & Plant height at 240 days $(\mathrm{cm})$ & $152.00-203.41$ & 179.11 & 252.62 & 446.63 \\
\hline 7 & Plant height at harvest $(\mathrm{cm})$ & $178.67-309.00$ & 271.03 & 887.62 & 1232.26 \\
\hline 8 & Cane diameter at harvest $(\mathrm{cm})$ & $2.23-3.18$ & 2.72 & 0.10 & 0.13 \\
\hline 9 & Fibre per cent at harvest & $12.75-14.72$ & 13.37 & 0.16 & 0.43 \\
\hline 10 & Single cane weight $(\mathrm{kg})$ & $0.71-1.19$ & 0.86 & 0.012 & 0.015 \\
\hline 11 & Number of millable cane at harvest (000/ha) & $98.57-122.60$ & 108.96 & 48.23 & 110.17 \\
\hline 12 & Brix per cent during 8 month stage & $16.34-20.27$ & 18.13 & 1.08 & 1.43 \\
\hline 13 & Pol per cent during 8 month stage & $14.01-17.55$ & 15.79 & 0.85 & 1.13 \\
\hline 14 & Purity per cent during 8 month stage & $85.80-88.67$ & 87.12 & 0.37 & 0.62 \\
\hline 15 & Brix per cent during 10 month stage & $19.97-21.93$ & 20.79 & 0.27 & 0.49 \\
\hline 16 & Pol per cent during 10 months stage & $17.51-18.95$ & 18.21 & 0.13 & 0.25 \\
\hline 17 & Purity per cent during 10 months stage & $86.30-89.13$ & 87.64 & 0.49 & 1.06 \\
\hline 18 & Cane yield (tonne/ha) & $71.83-119.68$ & 93.17 & 147.34 & 219.50 \\
\hline 19 & CCS per cent at harvest & $12.02-12.96$ & 12.54 & 0.05 & 0.10 \\
\hline 20 & Sugar yield (tonne/ha) & $8.91-15.12$ & 11.70 & 2.50 & 3.92 \\
\hline
\end{tabular}

$\left(\boldsymbol{\sigma}_{\mathrm{g}}{ }^{2}\right)$ Genotypic variance, $\left(\boldsymbol{\sigma}_{\mathrm{p}}{ }^{2}\right)$ Phenotypic variance 
Table.3 Estimate of GCV, PCV, h², GA and GAM of characters in early maturing Sugarcane clones

\begin{tabular}{|c|c|c|c|c|c|c|}
\hline S. $\mathbf{N}$. & Characters & GCV & PCV & $\mathbf{h}^{2}$ & GA $5 \%$ & GAM 5\% \\
\hline 1 & Germination percentage at $45 \mathrm{DAP}$ & 10.13 & 13.55 & 55.9 & 5.01 & 15.60 \\
\hline 2 & Germination percentage at $90 \mathrm{DAP}$ & 14.52 & 16.20 & 80.3 & 15.22 & 26.79 \\
\hline 3 & Number of shoots at $120 \mathrm{DAP}(000 / \mathrm{ha})$ & 11.57 & 13.05 & 78.6 & 22.19 & 21.14 \\
\hline 4 & Number of shoots at 240 DAP $(000 / \mathrm{ha})$ & 6.92 & 9.39 & 54.3 & 13.72 & 10.51 \\
\hline 5 & Plant height at 150 days $(\mathrm{cm})$ & 9.67 & 12.26 & 62.4 & 15.36 & 15.76 \\
\hline 6 & Plant height at 240 days $(\mathrm{cm})$ & 8.87 & 11.80 & 56.5 & 24.60 & 13.74 \\
\hline 7 & Plant height at harvest $(\mathrm{cm})$ & 10.99 & 12.95 & 72.0 & 52.09 & 19.22 \\
\hline 8 & Cane diameter at harvest $(\mathrm{cm})$ & 11.70 & 13.53 & 74.8 & 0.56 & 20.85 \\
\hline 9 & Fibre per cent at harvest & 3.01 & 4.9 & 37.3 & 0.51 & 3.78 \\
\hline 10 & Single cane weight $(\mathrm{kg})$ & 13.12 & 14.64 & 80.3 & 0.21 & 24.22 \\
\hline 11 & Number of millable cane at harvest $(000 / \mathrm{ha})$ & 6.37 & 9.63 & 43.8 & 9.47 & 8.67 \\
\hline 12 & Brix per cent during 8 month stage & 5.75 & 6.62 & 75.6 & 1.87 & 10.31 \\
\hline 13 & Pol per cent during 8 month stage & 5.85 & 6.78 & 75.3 & 1.65 & 10.46 \\
\hline 14 & Purity per cent during 8 month stage & 0.69 & 0.91 & 59.3 & 0.97 & 1.11 \\
\hline 15 & Brix per cent during 10 month stage & 2.54 & 3.37 & 56.9 & 0.82 & 3.94 \\
\hline 16 & Pol per cent during 10 month stage & 2.02 & 2.78 & 52.6 & 0.55 & 3.01 \\
\hline 17 & Purity per cent during 10 month stage & 0.80 & 1.17 & 46.5 & 0.97 & 1.12 \\
\hline 18 & Cane yield (tonne/ha) & 12.98 & 15.90 & 66.7 & 20.35 & 21.84 \\
\hline 19 & CCS per cent at harvest & 1.82 & 2.57 & 50.1 & 0.33 & 2.61 \\
\hline 20 & Sugar yield (tonne/ha) & 13.51 & 16.93 & 63.7 & 2.60 & 22.61 \\
\hline
\end{tabular}

Phenotypic Coefficient of Variance (PCV), Genotypic Coefficient of Variance (GCV), Heritability ( $\left.{ }^{2}\right)$, Genetic Advance (GA) and Genetic Advance as per cent of Mean (GAM) 
Graph.1 Estimate of ECV, GCV, PCV, h² and GAM of characters in early maturing Sugarcane clones

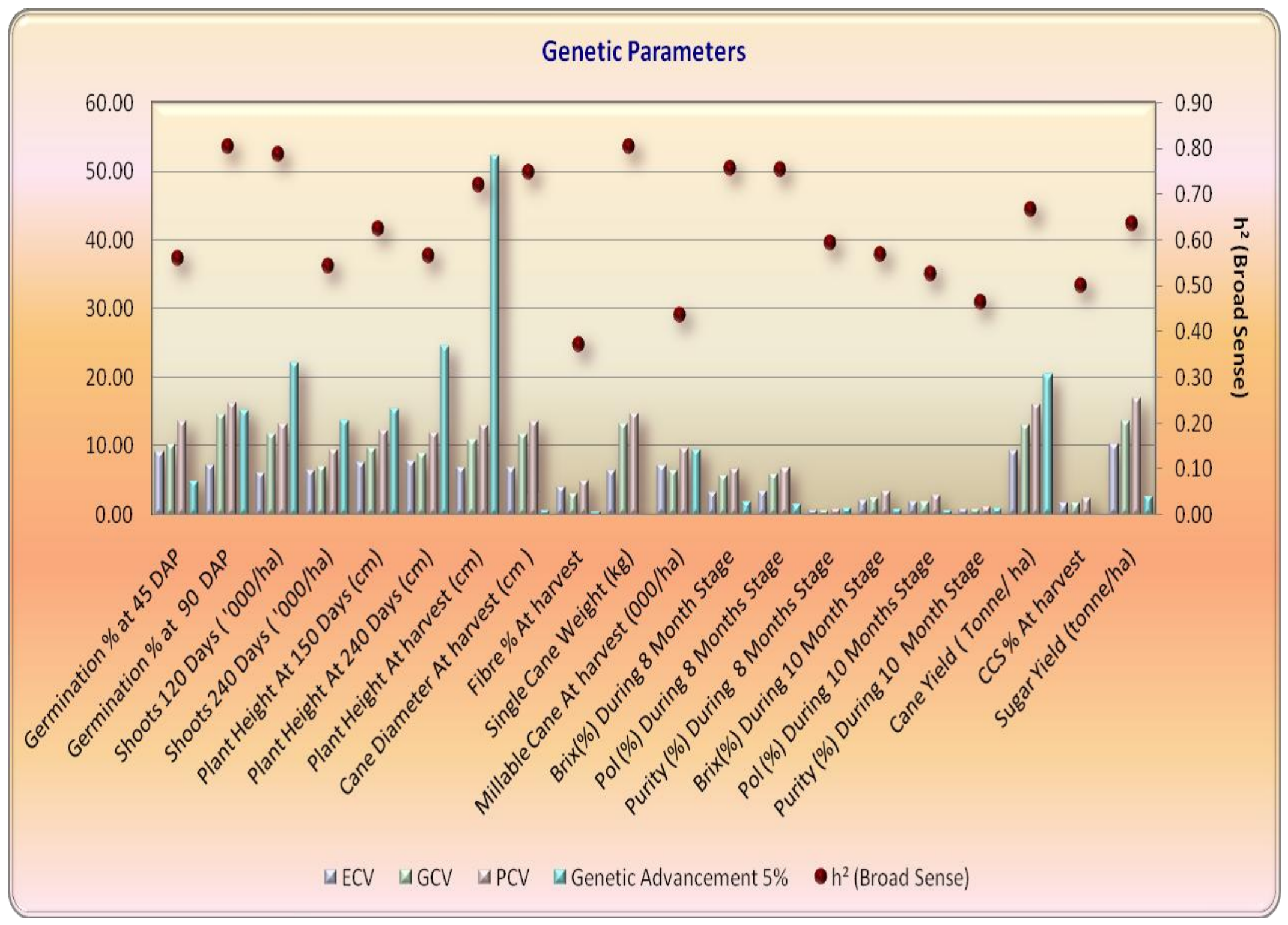


In order to make selection more effective, six characters were used in present investigation viz. selection based on per se performance of characters namely, cane yield, sugar yield, single cane weight, cane diameter, germination percentage at 90 DAP, number of shoots at 120 DAP as these characters showed high heritability coupled with genetic advance as per of mean. Therefore, instead of 20 traits only six traits cane be observed for further improvement in early maturing sugarcane clones.

\section{References}

Agrawal, R. K., and Kumar, B. 2017. Genetic Divergence in Sugarcane under WaterLogging Condition and Identification of Tolerant Clones. Int.J.Curr.Microbiol. App.Sci., 6(7): 4044-4055.

Allard, R.W. (1960). Principles of Plant Breeding. John Wiley and Sons Inc. London: 83-108.

Bairwa, A.K., Ram, R., Neetu., Jeena, A.S., Kamendra. and Singh, S.P. 2017. Estimation of the extent of variability for different Morphological and Juice quality among early generation sugarcane clones. International Journal of current Microbiology and Applied Sciences, 6(2): 1272-1278.

Chaudhary, R., 2001. Genetic variability and heritability in sugarcane. Nepal Agric. Res. J., 4\&5.

Dilnesaw, Z., Tadesse, F., Biquila, M., Goshu, F. and Tolera, B. 2016. Participatory variety selection genetic variability and heritability of ten exotic commercial sugarcane varieties at Fincha Sugar Factory Huru Gudro Zone Oromiya Regional State Ethiopia. EC Agriculture, 3.4: 719-727.

Doule, R.B., and Balasundram, N. 2002. Genetic variability in sugar yield and its components for selection of sugarcane. Journal of Maharashtra Agricultural
Universities, 27(3):326-327.

Ebid, M.H.M., Khalil, H.A., Abd- El Aal, A.M. and Fergany, M.A. 2015. Heritabiity and genotypic and phenotypic correlations among sugarcane yield and some agronomic traits. Egypt J. Plant Breed, 19(1): 159179.

Hiremath, G., and Nagaraja, T.E. 2016. Genetic variability and heritability analysis in selected clones of sugarcane. International Journal of science technology and engineering, 2(8): 2349$784 \mathrm{X}$.

Jamoza, J.E., Ownocha, J., Kiplagat, O. and Opile, W. 2014. Broad-sense heritability estimation and correlation among sugarcane (Sacharum spp. Hybrids) yield and some agronomic traits in Western Kenya. International Journal of Agricultural Policy and Research, 2(1): 016-025.

Johnson, H.W., Robinson, H.F. and Comstock, R.E. 1955. Estimates of phenotypic and genotypic correlation in soybean and their implication in selection. Agronomic Journal, 47: 477482.

Kumar, K., Singh, P.K. and Singh, J.R.P. 2004. Genetic variability and character association in sub-tropical clones of sugarcane (Saccharum complex hybrid). Indian Sugar, 54(3):189-198.

Kumar, P., Kumar B. and Chandra, K. 2017. Estimation of Extent of Variability for Various Productive Traits in Sugarcane under Water-Logged Condition. Int.J.Curr.Microbiol.App.Sci. $\quad$ 6(7): 1187-1192.

Lush, J.L., 1949. Heritability of quantitative characters in farm animals. Proceedings of $8^{\text {th }}$ Congress of Genetics and Heriditas, 35: 356-375.

Mali, S.C., Patel, A.I., Patel, D.U. and Patel, C.L. 2010. Variability, correlation, path analysis and genetic divergence in 
sugarcane (Saccharum spp.). Research on Crops, 11(2): 497-504.

Mehareb, E.M., and Abazid, S.R. 2017. Genetic variability of some promising varieties (Saccharum spp) under harvesting ages for juice quality traits, cane and sugar yield. Open access Journal of Agricultural research.

Panse, V.G., and Sukhatme, P.V. 1967. Statistical methods for Agricultural Research Works. III edition, ICAR, New Delhi.

Robinson, H.F., Comstock, R.E. and Harvey, P.H. 1949. Genotypic and phenotypic correlation's in corn and their implications in selection. Agronomy Journal, 43: 282-287.

Sanghera, G.S., Tyagi, V., Kumar, R., Thind, K.S. and Sharma, B. 2015. Genetic variability, association and their and their dissection through path analysis for cane yield and its component traits in early maturing sugarcane clones. Journal of Science, 5: 28-34.

Swamy Gowda, S.N., Saravanan, K. and
Ravishankar, C.R. 2016. Genetic variability, heritability and genetic advance in selected clones of sugarcane. Plant Archives, 16(2): 700-704.

Tadesse, F., and Dilnesaw, Z. 2014. Genetic variability, heritability and character association of twelve sugar cane varieties in Fincha Sugar Factory Huru Gudro Zone Oromiya Regional State Ethiopia. International Journal of advanced research in biological science. 1(7): 131-137.

Tena, E., Mekbib, F. and Ayana, A. 2016. Correlation and path coefficient analyses in sugarcane genotypes of Ethiopia. American Journal of Plant Science, 7: 1490-1497.

Thippeswamy, S., Kajjidoni, S.T., Slimath, P.M., Goud, J.V. and Chetti, M.B. 2001.Variability, heritability and genetic advance for cane yield and its component traits in sugarcane. Sugar Tech, 5(1/2): 65-72.

\section{How to cite this article:}

Relisha Ranjan and Balwant Kumar. 2017. Study of Genetic Variability for Cane Yield and its Component Traits in Early Maturing Sugarcane. Int.J.Curr.Microbiol.App.Sci. 6(10): 17391748. doi: https://doi.org/10.20546/ijcmas.2017.610.210 